\title{
Dimensions and Clusters of Aesthetic Emotions: A Semantic Profile Analysis
}

\section{Supplementary Material}

Ursula Beermann ${ }^{1}$, Georg Hosoya ${ }^{2}$, Ines Schindler ${ }^{3}$, Klaus R. Scherer ${ }^{4} 5^{*}$, Michael Eid ${ }^{2}$, Valentin Wagner $^{3,6}$, and Winfried Menninghaus ${ }^{3}$

${ }^{1}$ Department of Psychology, UMIT - Private University for Health Sciences, Medical Informatics and Technology, Hall in Tirol, Austria.

${ }^{2}$ Department of Education and Psychology, Division of Methods and Evaluation, Freie Universität Berlin, Berlin, Germany.

${ }^{3}$ Max Planck Institute for Empirical Aesthetics, Frankfurt am Main, Germany.

${ }^{4}$ Department of Psychology, University of Geneva, Geneva, Switzerland.

${ }^{5}$ Department of Psychology, Ludwig-Maximilians-University Munich, Munich, Germany.

${ }^{6}$ Humanities and Social Sciences, Helmut Schmidt University/University of the Federal Armed Forces Hamburg, Hamburg, Germany. 


\section{Supplementary Table 1}

Inter-rater Consistency (Cronbach $\alpha$ ) for Each of the 75 Emotion Terms Across the CoreGRID Features (Uncentered Scores), Sorted From Highest to Lowest $\alpha$ Coefficient

\begin{tabular}{|c|c|c|c|c|c|c|c|}
\hline Nr. & German & English & Group & $\alpha_{C}$ & $N_{\mathrm{C}}$ & $\alpha_{\mathrm{A}}$ & $N_{\mathrm{A}}$ \\
\hline 7 & Beruhigte mich & Calmed me & 11 & .959 & 15 & .959 & 15 \\
\hline 55 & $\begin{array}{l}\text { Empfand ich als } \\
\text { angenehm }\end{array}$ & I found it pleasant & 7 & .959 & 15 & .959 & 15 \\
\hline 10 & Machte mich zufrieden & Made me feel content & 5 & .957 & 16 & .957 & 16 \\
\hline 11 & Machte mich glücklich & Made me happy & 6 & .957 & 16 & .957 & 16 \\
\hline 4 & Stimmte mich fröhlich & Made me cheerful & 2 & .956 & 17 & .956 & 17 \\
\hline 13 & Erfreute mich & Delighted me & 9 & .955 & 15 & .955 & 15 \\
\hline 30 & Begeisterte mich & $\begin{array}{l}\text { Made me feel } \\
\text { enthusiastic }\end{array}$ & 11 & .954 & 14 & .946 & 15 \\
\hline 39 & Energetisierte mich & Energized me & 6 & .952 & 16 & .952 & 16 \\
\hline 56 & Beängstigte mich & Scared me & 7 & .951 & 15 & .951 & 15 \\
\hline 74 & Entspannte mich & Relaxed me & 8 & .950 & 16 & .950 & 16 \\
\hline 28 & Empfand ich als schön & I found it beautiful & 4 & .949 & 16 & .949 & 16 \\
\hline 26 & Schockierte mich & Was shocking to me & 2 & .946 & 17 & .946 & 17 \\
\hline 8 & Stimmte mich ärgerlich & Made me angry & 11 & .945 & 14 & .936 & 15 \\
\hline 35 & Machte mich aggressiv & Made me aggressive & 4 & .944 & 16 & .944 & 16 \\
\hline 37 & $\begin{array}{l}\text { Fühlte etwas } \\
\text { Wunderbares }\end{array}$ & $\begin{array}{l}\text { Felt something } \\
\text { wonderful }\end{array}$ & 4 & .944 & 16 & .934 & 16 \\
\hline 25 & Gefiel mir & Liked it & 3 & .942 & 16 & .942 & 16 \\
\hline 61 & Fühlte mich verwirrt & Felt confused & 5 & .942 & 15 & .924 & 16 \\
\hline 5 & $\begin{array}{l}\text { Wirkte auf mich } \\
\text { beklemmend }\end{array}$ & Felt oppressive & 11 & .941 & 14 & .933 & 15 \\
\hline 52 & Machte mich munter & Perked me up & 7 & .941 & 14 & .929 & 15 \\
\hline 71 & Amüsierte mich & Amused me & 9 & .937 & 15 & .937 & 15 \\
\hline 14 & $\begin{array}{l}\text { Empfand ich als } \\
\text { vollkommen }\end{array}$ & I found it perfect & 11 & .935 & 14 & .927 & 15 \\
\hline 47 & Wühlte mich auf & Agitated me & 4 & .935 & 16 & .935 & 16 \\
\hline 44 & Überraschte mich & Surprised me & 7 & .933 & 14 & .921 & 15 \\
\hline 72 & $\begin{array}{l}\text { Empfand ich als } \\
\text { harmonisch }\end{array}$ & I found it harmonious & 10 & .932 & 15 & .932 & 15 \\
\hline 16 & Beunruhigte mich & Worried me & 10 & .931 & 15 & .931 & 15 \\
\hline 34 & Machte mich neugierig & Made me curious & 11 & .931 & 15 & .931 & 15 \\
\hline 63 & $\begin{array}{l}\text { Empfand ich als } \\
\text { geschmacklos }\end{array}$ & I found it distasteful & 9 & .930 & 15 & .930 & 15 \\
\hline 2 & Beflügelte mich & Spurred me on & 3 & .929 & 16 & .929 & 16 \\
\hline 54 & $\begin{array}{l}\text { Fühlte mich in der } \\
\text { Erfahrung aufgehen }\end{array}$ & $\begin{array}{l}\text { Felt absorbed in the } \\
\text { experience }\end{array}$ & 5 & .929 & 15 & .919 & 16 \\
\hline 42 & Inspirierte mich & Inspired me & 5 & .928 & 15 & .919 & 16 \\
\hline 22 & Fühlte mich bedrückt & Felt depressed & 4 & .927 & 15 & .923 & 16 \\
\hline
\end{tabular}




\begin{tabular}{|c|c|c|c|c|c|c|c|}
\hline Nr. & German & English & Group & $\alpha_{C}$ & $N_{\mathrm{C}}$ & $\alpha_{A}$ & $N_{\mathrm{A}}$ \\
\hline 60 & $\begin{array}{l}\text { Empfand ich als } \\
\text { unangenehm }\end{array}$ & I found it unpleasant & 9 & .927 & 15 & .927 & 15 \\
\hline 27 & Stieß mich ab & Repelled me & 2 & .926 & 17 & .926 & 17 \\
\hline 3 & Belebte mich & Invigorated me & 10 & .923 & 15 & .923 & 15 \\
\hline 40 & Irritierte mich & Irritated me & 7 & .923 & 15 & .923 & 15 \\
\hline 64 & War mir gleichgültig & Felt indifferent & 4 & .923 & 16 & .923 & 16 \\
\hline 21 & Behagte mir nicht & $\begin{array}{l}\text { Made me feel } \\
\text { uncomfortable }\end{array}$ & 3 & .920 & 12 & .882 & 16 \\
\hline 53 & $\begin{array}{l}\text { Weckte meinen } \\
\text { Tatendrang }\end{array}$ & Motivated me to act & 9 & .920 & 15 & .920 & 15 \\
\hline 70 & $\begin{array}{l}\text { Versetzte mich in } \\
\text { träumerische Stimmung }\end{array}$ & Put me in a dreamy mood & 9 & .917 & 15 & .917 & 15 \\
\hline 59 & Belustigte mich & Was funny to me & 6 & .916 & 16 & .916 & 16 \\
\hline 69 & Verstörte mich & Was unsettling to me & 8 & .916 & 15 & .905 & 16 \\
\hline 43 & Erheiterte mich & Made me merry & 3 & .915 & 15 & .909 & 16 \\
\hline 46 & Weckte mein Interesse & Sparked my interest & 4 & .915 & 16 & .915 & 16 \\
\hline 50 & War wie verzaubert & Was enchanted & 7 & .913 & 15 & .913 & 15 \\
\hline 29 & Zog mich an & Was attracted & 6 & .912 & 16 & .912 & 16 \\
\hline 19 & War beeindruckt & Was impressed & 6 & .910 & 16 & .910 & 16 \\
\hline 31 & Verblüffte mich & Baffled me & 4 & .906 & 15 & .900 & 16 \\
\hline 67 & Stimmte mich traurig & Made me sad & 10 & .906 & 15 & .906 & 15 \\
\hline 38 & Ermüdete mich & Tired me & 11 & .905 & 15 & .905 & 15 \\
\hline 68 & Langweilte mich & Bored me & 7 & .899 & 15 & .899 & 15 \\
\hline 6 & Packte mich & Gripped me & 3 & .888 & 15 & .882 & 16 \\
\hline 9 & $\begin{array}{l}\text { Empfand ich als } \\
\text { erhaben }\end{array}$ & I found it sublime & 2 & .887 & 15 & .862 & 17 \\
\hline 49 & War überwältigt & Was overwhelmed & 9 & .886 & 13 & .864 & 15 \\
\hline 36 & Missfiel mir & Disliked it & 6 & .885 & 16 & .885 & 16 \\
\hline 75 & Faszinierte mich & Fascinated me & 8 & .884 & 15 & .881 & 16 \\
\hline 15 & War ergriffen & Felt deeply moved & 5 & .876 & 14 & .834 & 16 \\
\hline 65 & War hingerissen & Was enraptured & 10 & .872 & 13 & .809 & 15 \\
\hline 58 & $\begin{array}{l}\text { Empfand ich als } \\
\text { hässlich }\end{array}$ & I found it ugly & 6 & .871 & 15 & .867 & 16 \\
\hline 32 & Empfand Demut & Felt humbled & 5 & .869 & 13 & .799 & 16 \\
\hline 45 & $\begin{array}{l}\text { Spürte einen tieferen } \\
\text { Sinn }\end{array}$ & Sensed a deeper meaning & 8 & .858 & 13 & .835 & 16 \\
\hline 48 & $\begin{array}{l}\text { Empfand ich als } \\
\text { anmutig }\end{array}$ & I found it graceful & 8 & .857 & 14 & .85 & 16 \\
\hline 57 & $\begin{array}{l}\text { Versetzte mich in } \\
\text { Staunen }\end{array}$ & Astonished me & 10 & .855 & 14 & .841 & 15 \\
\hline 17 & $\begin{array}{l}\text { Forderte mich } \\
\text { intellektuell heraus }\end{array}$ & $\begin{array}{l}\text { Challenged me } \\
\text { intellectually }\end{array}$ & 2 & .854 & 15 & .833 & 17 \\
\hline 12 & Berührte mich & Touched me & 2 & .853 & 16 & .846 & 17 \\
\hline 24 & War geistig gefordert & Was mentally engaged & 5 & .851 & 14 & .811 & 16 \\
\hline
\end{tabular}


DIMENSIONS AND CLUSTERS OF AESTHETIC EMOTIONS

\begin{tabular}{|c|c|c|c|c|c|c|c|}
\hline $\mathrm{Nr}$. & German & English & Group & $\alpha_{C}$ & $N_{\mathrm{C}}$ & $\alpha_{\mathrm{A}}$ & $N_{\mathrm{A}}$ \\
\hline 20 & $\begin{array}{l}\text { Stimmte mich } \\
\text { melancholisch }\end{array}$ & $\begin{array}{l}\text { Made me feel } \\
\text { melancholic }\end{array}$ & 3 & .839 & 15 & .83 & 16 \\
\hline 18 & $\begin{array}{l}\text { War mir meiner selbst } \\
\text { nicht bewusst }\end{array}$ & Was not aware of myself & 2 & .833 & 11 & .736 & 17 \\
\hline 73 & $\begin{array}{l}\text { Regte meine Gedanken } \\
\text { an }\end{array}$ & Stimulated my thoughts & 9 & .832 & 13 & .799 & 15 \\
\hline 62 & $\begin{array}{l}\text { Spürte die Zeit wie im } \\
\text { Flug vergehen }\end{array}$ & Felt that time is flying & 8 & .826 & 14 & .787 & 16 \\
\hline 66 & Bewegte mich & Moved me & 8 & .790 & 15 & .775 & 16 \\
\hline 23 & $\begin{array}{l}\text { Fühlte eine plötzliche } \\
\text { Einsicht }\end{array}$ & Felt a sudden insight & 2 & .789 & 14 & .734 & 17 \\
\hline 41 & $\begin{array}{l}\text { Weckte in mir } \\
\text { sentimentale Gefühle }\end{array}$ & $\begin{array}{l}\text { Made me feel } \\
\text { sentimental }\end{array}$ & 10 & .787 & 13 & .768 & 15 \\
\hline 51 & Empfand Ehrfurcht & Felt awe & 8 & .757 & 12 & .659 & 16 \\
\hline 33 & $\begin{array}{l}\text { Machte mich } \\
\text { nostalgisch }\end{array}$ & Made me feel nostalgic & 6 & .739 & 13 & .721 & 16 \\
\hline 1 & $\begin{array}{l}\text { Weckte in mir } \\
\text { Sehnsucht }\end{array}$ & Filled me with longing & 3 & .719 & 12 & .667 & 16 \\
\hline
\end{tabular}

Note. Group = Emotion group in which the phrase was presented within the study. $N_{\mathrm{C}}=$ Sample size of converging raters; $N_{\mathrm{A}}=$ Sample size of all raters; $\alpha_{\mathrm{C}}=$ Cronbach's

Alpha across only converging raters (participant-rest correlation $\geq .20$ ); $\alpha_{\mathrm{A}}=$ Cronbach's Alpha across all raters (see Fontaine et al., 2013). 
DIMENSIONS AND CLUSTERS OF AESTHETIC EMOTIONS

\section{Supplementary Table 2}

German Features, their English Translations and the Respective Component of Each Feature according to the CPM (Scherer, 2013)

\begin{tabular}{llll}
\hline Nr. & \multicolumn{1}{c}{ Feature (German) } & Feature (English) & Component \\
\hline 3 & Gut & Good & Feeling \\
4 & Müde & Tired & Feeling \\
5 & Unruhig & Restless & Feeling \\
6 & Stark & Strong & Feeling \\
7 & Ruhig & Calm & Feeling \\
8 & Schlecht & Bad & Feeling \\
9 & Schwach & Weak & Feeling \\
10 & Wach & Awake & Feeling \\
11 & Sich schwach in den Gliedern fühlen & Feeling weak in the limbs & Body \\
12 & Blass werden & Becoming pale & Body \\
13 & Magenbeschwerden & Stomach disturbance & Body \\
14 & Verlangsamter Herzschlag & Slowed heart rate & Body \\
15 & Beschleunigter Herzschlag & Rapid heart rate & Body \\
16 & Muskelanspannung & Tense muscles & Body \\
17 & Verlangsamte Atmung & Slowed breathing & Body \\
18 & Beschleunigte Atmung & Rapid breathing & Body \\
19 & Sich warm fühlen & Feeling warm & Body \\
20 & Schwitzen & Sweating & Body \\
21 & Sich kalt fühlen & Feeling cold & Body \\
22 & Lächelte & Smiled & Expression \\
23 & Die Kinnlade fallen ließ & Dropped their jaw & Expression \\
24 & Die Augenbrauen hoch zog & Raised the eyebrows & Expression \\
25 & Die Stirn runzelte & Frowned & Expression \\
\hline
\end{tabular}




\begin{tabular}{|c|c|c|c|}
\hline $\mathrm{Nr}$. & Feature (German) & Feature (English) & Component \\
\hline 26 & Die Augen schloss & Closed the eyes & Expression \\
\hline 27 & Tränen in den Augen hatte & Had tears in the eyes & Expression \\
\hline 28 & Lauter sprach & Spoke more loudly & Expression \\
\hline 29 & Mit zitternder Stimme sprach & Spoke in a trembling voice & Expression \\
\hline 30 & Mit fester Stimme sprach & Spoke in a firm voice & Expression \\
\hline 31 & Sprechprobleme hatte & Had speech disturbances & Expression \\
\hline 32 & Langsamer sprach & Spoke more slowly & Expression \\
\hline 33 & Schneller sprach & Spoke more rapidly & Expression \\
\hline 34 & $\begin{array}{l}\text { Wollte, dass die Situation weiter andauert oder sich } \\
\text { wiederholt }\end{array}$ & Wanted the ongoing situation to last or be repeated & Behavior \\
\hline 35 & Beenden wollte, was er/sie gerade tat & Wanted to stop what he/she was doing & Behavior \\
\hline 36 & Das, was gerade passierte, rückgängig machen wollte & Wanted to undo what was happening & Behavior \\
\hline 37 & $\begin{array}{l}\text { Sich nach den Wünschen von jemand anderem richten } \\
\text { wollte }\end{array}$ & Wanted to comply with someone else's wishes & Behavior \\
\hline 38 & Die Initiative jemand anderem überlassen wollte & Wanted someone else to take the initiative & Behavior \\
\hline 39 & Nichts machen wollte & Wanted to do nothing & Behavior \\
\hline 40 & $\begin{array}{l}\text { Keine Lust hatte, die Aufmerksamkeit auf das zu } \\
\text { richten, was gerade passierte }\end{array}$ & $\begin{array}{l}\text { Lacked the motivation to pay attention to what was } \\
\text { happening }\end{array}$ & Behavior \\
\hline 41 & Verschwinden oder sich vor anderen verstecken wollte & Wanted to disappear or hide from others & Behavior \\
\hline 42 & $\begin{array}{l}\text { Schaden anrichten, zuschlagen oder etwas } \\
\text { Verletzendes sagen wollte }\end{array}$ & Wanted to do damage, hit, or say something that hurts & Behavior \\
\hline 43 & Sich jemandem oder etwas widersetzen wollte & Wanted to oppose someone or something & Behavior \\
\hline 44 & Die Situation meistern wollte & Wanted to tackle the situation & Behavior \\
\hline 45 & Ein Hindernis überwinden wollte & Wanted to overcome an obstacle & Behavior \\
\hline 46 & In irgendeine Richtung wegrennen wollte & Wanted to run away in any direction & Behavior \\
\hline 47 & Singen oder tanzen wollte & Wanted to sing and dance & Behavior \\
\hline
\end{tabular}




\begin{tabular}{|c|c|c|c|}
\hline $\mathrm{Nr}$. & Feature (German) & Feature (English) & Component \\
\hline 48 & Das Ereignis plötzlich auftrat & The event occurred suddenly & Evaluation \\
\hline 49 & Das Ereignis unvorhersehbar war & The event was unpredictable & Evaluation \\
\hline 50 & Das Ereignis die Erwartungen der Person bestätigte & The event confirmed the expectations of the person & Evaluation \\
\hline 51 & Das Ereignis angenehm für die Person war & The event was pleasant for the person & Evaluation \\
\hline 52 & $\begin{array}{l}\text { Das Ereignis wichtig und relevant für die Ziele und } \\
\text { Bedürfnisse der Person war }\end{array}$ & $\begin{array}{l}\text { The event was important for and relevant to the person's } \\
\text { goals or needs }\end{array}$ & Evaluation \\
\hline 53 & $\begin{array}{l}\text { Das Ereignis wichtig und relevant für die Ziele und } \\
\text { Bedürfnisse von jemand anderem war }\end{array}$ & $\begin{array}{l}\text { The event was important for and relevant to the goals or } \\
\text { needs of somebody else }\end{array}$ & Evaluation \\
\hline 54 & Das Ereignis zufällig passierte & The event happened by chance & Evaluation \\
\hline 55 & $\begin{array}{l}\text { Das Ereignis durch das eigene Verhalten der Person } \\
\text { verursacht wurde }\end{array}$ & The event was caused by the person's own behavior & Evaluation \\
\hline 56 & $\begin{array}{l}\text { Das Ereignis durch das Verhalten von jemand anderem } \\
\text { verursacht wurde }\end{array}$ & The event was caused by somebody else's behavior & Evaluation \\
\hline 57 & Das Ereignis vorhersehbare Konsequenzen hatte & The event had consequences that were predictable & Evaluation \\
\hline 58 & $\begin{array}{l}\text { Das Ereignis negative, unerwünschte Konsequenzen } \\
\text { für die Person hatte }\end{array}$ & $\begin{array}{l}\text { The event had negative, undesirable consequences for } \\
\text { the person }\end{array}$ & Evaluation \\
\hline 59 & Das Ereignis sofortiges Handeln erforderte & The event required an immediate response & Evaluation \\
\hline 60 & $\begin{array}{l}\text { Die Person Macht über die Konsequenzen des } \\
\text { Ereignisses hatte }\end{array}$ & $\begin{array}{l}\text { The person had power over the consequences of the } \\
\text { event }\end{array}$ & Evaluation \\
\hline 61 & $\begin{array}{l}\text { Die Person Kontrolle über die Konsequenzen des } \\
\text { Ereignisses hatte }\end{array}$ & $\begin{array}{l}\text { The person had control over the consequences of the } \\
\text { event }\end{array}$ & Evaluation \\
\hline 62 & $\begin{array}{l}\text { Die Person mit den Konsequenzen des Ereignisses } \\
\text { leben konnte }\end{array}$ & $\begin{array}{l}\text { The person could live with the consequences of the } \\
\text { event }\end{array}$ & Evaluation \\
\hline 63 & $\begin{array}{l}\text { Das Ereignis unvereinbar mit den Ansprüchen und } \\
\text { Idealen der Person war }\end{array}$ & $\begin{array}{l}\text { The event was inconsistent with the person's } \\
\text { own standards and ideals }\end{array}$ & Evaluation \\
\hline
\end{tabular}


DIMENSIONS AND CLUSTERS OF AESTHETIC EMOTIONS

\begin{tabular}{|c|c|c|c|}
\hline $\mathrm{Nr}$. & Feature (German) & Feature (English) & Component \\
\hline 64 & $\begin{array}{l}\text { Das Ereignis eine Verletzung von sozial-akzeptierten } \\
\text { Standards mit sich brachte }\end{array}$ & $\begin{array}{l}\text { The event involved the violation of socially accepted } \\
\text { norms }\end{array}$ & Evaluation \\
\hline 65 & Die Person während dieses Ereignisses machtlos war & $\begin{array}{l}\text { The person was powerless in this situation involving the } \\
\text { event }\end{array}$ & Evaluation \\
\hline 66 & $\begin{array}{l}\text { Die Person eine dominante Position während dieses } \\
\text { Ereignisses hatte }\end{array}$ & $\begin{array}{l}\text { The person had a dominant role in the situation } \\
\text { involving the event }\end{array}$ & Evaluation \\
\hline 67 & $\begin{array}{l}\text { Es keinen Grund zur Eile während dieses Ereignisses } \\
\text { gab }\end{array}$ & $\begin{array}{l}\text { There was no urgency in the situation involving the } \\
\text { event }\end{array}$ & Evaluation \\
\hline 68 & Das Ereignis unkontrollierbar war & The event was uncontrollable & Evaluation \\
\hline
\end{tabular}




\section{Supplementary Table 3}

Rotated Component Matrix of the GRID Features Resulting from a Principal Component Analyses Using Orthogonal Equamax Rotation, Extracting 3 Dimensions

\begin{tabular}{|c|c|c|c|c|c|}
\hline Feature & Comp. & Comm. & Valence & Arousal & Power \\
\hline Wanted the ongoing situation to last or be repeated & $\mathrm{Be}$ & .977 & -.904 & .011 & -.399 \\
\hline The event was inconsistent with the person's own standards and ideals & Ev & .933 & .895 & .120 & .342 \\
\hline Wanted to undo what was happening & $\mathrm{Be}$ & .942 & .882 & -.055 & .402 \\
\hline Smiled & Ex & .951 & -.875 & -.044 & -.429 \\
\hline Wanted to stop what he/she was doing & $\mathrm{Be}$ & .894 & .874 & -.167 & .319 \\
\hline The event had negative, undesirable consequences for the person & Ev & .938 & .867 & .088 & .422 \\
\hline Bad & $\mathrm{F}$ & .944 & .866 & -.097 & .430 \\
\hline Feeling warm & Bo & .897 & -.849 & -.067 & -.415 \\
\hline Wanted to sing and dance & $\mathrm{Be}$ & .917 & -.844 & .109 & -.440 \\
\hline Wanted to oppose someone or something & $\mathrm{Be}$ & .853 & .839 & .385 & -.013 \\
\hline Wanted to disappear or hide from others & $\mathrm{Be}$ & .912 & .776 & -.147 & .537 \\
\hline Feeling cold & Bo & .894 & .771 & -.297 & .460 \\
\hline The event was important for and relevant to the person's goals or needs & Ev & .791 & -.761 & .157 & -.432 \\
\hline The person could live with the consequences of the event & Ev & .806 & -.711 & -.315 & -.449 \\
\hline Restless & $\mathrm{F}$ & .859 & .710 & .487 & .341 \\
\hline
\end{tabular}


DIMENSIONS AND CLUSTERS OF AESTHETIC EMOTIONS

\begin{tabular}{|c|c|c|c|c|c|}
\hline Feature & Comp. & Comm. & Valence & Arousal & Power \\
\hline Strong & $\mathrm{F}$ & .907 & -.687 & .202 & -.628 \\
\hline The event was important for and relevant to the goals or needs of somebody else & Ev & .617 & -.680 & .130 & -.372 \\
\hline Lacked the motivation to pay attention to what was happening & $\mathrm{Be}$ & .803 & .665 & -.563 & .208 \\
\hline 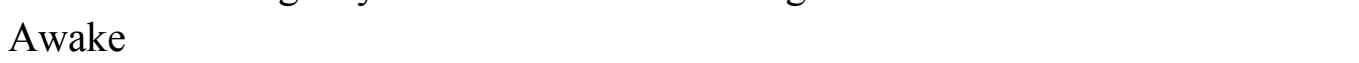 & $\mathrm{F}$ & .805 & -.569 & .483 & -.498 \\
\hline Wanted to comply with someone else's wishes & $\mathrm{Be}$ & .550 & -.547 & -.499 & -.026 \\
\hline Slowed heart rate & Bo & .929 & -.205 & -.932 & -.141 \\
\hline Rapid heart rate & Bo & .862 & -.141 & .915 & .071 \\
\hline Slowed breathing & Bo & .891 & -.258 & -.902 & -.104 \\
\hline Rapid breathing & Bo & .832 & -.036 & .901 & .135 \\
\hline Wanted to do nothing & $\mathrm{Be}$ & .843 & .039 & -.882 & .253 \\
\hline Tense muscles & Bo & .825 & .249 & .870 & .072 \\
\hline Spoke more rapidly & Ex & .853 & -.211 & .869 & -.233 \\
\hline Spoke more loudly & Ex & .785 & -.133 & .788 & -.382 \\
\hline Sweating & Bo & .770 & .338 & .784 & .202 \\
\hline The event was unpredictable & Ev & .697 & .035 & .763 & .337 \\
\hline The event required an immediate response & Ev & .760 & .457 & .730 & -.136 \\
\hline Calm & $\mathrm{F}$ & .909 & -.568 & -.694 & -.325 \\
\hline Wanted someone else to take the initiative & $\mathrm{Be}$ & .688 & .320 & -.647 & .409 \\
\hline Dropped their jaw & Ex & .518 & -.167 & .639 & .285 \\
\hline Raised the eyebrows & Ex & .458 & .205 & .632 & .128 \\
\hline
\end{tabular}




\begin{tabular}{|c|c|c|c|c|c|}
\hline Feature & Comp. & Comm. & Valence & Arousal & Power \\
\hline The event happened by chance & $\mathrm{Ev}$ & .550 & -.387 & .617 & .139 \\
\hline The event had consequences that were predictable & Ev & .637 & -.236 & -.587 & -.487 \\
\hline Spoke in a firm voice & Ex & .871 & -.406 & .133 & -.829 \\
\hline Spoke in a trembling voice & Ex & .780 & .268 & .268 & .797 \\
\hline Had speech disturbances & Ex & .788 & .233 & .371 & .772 \\
\hline The person had power over the consequences of the event & Ev & .854 & -.536 & -.158 & -.736 \\
\hline The person was powerless in this situation involving the event & Ev & .853 & .599 & .057 & .701 \\
\hline The event was caused by the person's own behavior & Ev & .714 & -.377 & -.291 & -.698 \\
\hline Becoming pale & Bo & .871 & .639 & -.006 & .680 \\
\hline Wanted to overcome an obstacle & $\mathrm{Be}$ & 699 & -.034 & .556 & -.624 \\
\hline Had tears in the eyes & Ex & .386 & -.295 & -.040 & .545 \\
\hline The event was caused by somebody else's behavior & Ev & .335 & .194 & .323 & .439 \\
\hline
\end{tabular}

Note. Comp. $=$ Component according to the CPM. Comm. = Communality. $\mathrm{F}=$ Subjective Feeling, Bo=Bodily Reactions, Ex=Expression, $\mathrm{Be}=$ Behavior Tendencies, Ev=Event Evaluation. Boldface indicates the highest loading of each feature. The feature loadings indicate that the two dimensions valence and power are inverted: for valence, positive loadings represent negative valence; for power, positive loadings stand for low power, and vice versa. 


\section{Supplementary Table 4}

Rotated Component Matrix of the GRID Features Resulting from a Principal Component Analyses Using Orthogonal Equamax Rotation, Extracting 3 Dimensions

\begin{tabular}{|c|c|c|c|c|c|c|c|}
\hline Feature & Comp. & Comm. & Valence & Arousal & $\begin{array}{c}\text { Power } \\
\text { Motivation }\end{array}$ & $\begin{array}{c}\text { Power } \\
\text { Potential }\end{array}$ & Novelty \\
\hline Wanted to oppose someone or something & $\mathrm{Be}$ & .882 & .807 & .413 & .198 & .123 & .072 \\
\hline Frowned & Ex & .887 & .760 & -.095 & .296 & .109 & .449 \\
\hline Wanted to do damage, hit, or say something that hurts & $\mathrm{Be}$ & .856 & .750 & .242 & .402 & .250 & .111 \\
\hline $\begin{array}{l}\text { The event was inconsistent with the person's own } \\
\text { standards and ideals }\end{array}$ & Ev & .935 & .744 & .131 & .481 & .350 & .106 \\
\hline Wanted the ongoing situation to last or be repeated & $\mathrm{Be}$ & .978 & -.722 & .010 & -.566 & -.352 & -.111 \\
\hline The event was pleasant for the person & Ev & .978 & -.716 & -.047 & -.511 & -.425 & -.147 \\
\hline Smiled & Ex & .952 & -.713 & -.029 & -.507 & -.409 & -.133 \\
\hline $\begin{array}{l}\text { The event had negative, undesirable consequences for the } \\
\text { person }\end{array}$ & Ev & .950 & .707 & .113 & .484 & .445 & .072 \\
\hline Wanted to undo what was happening & $\mathrm{Be}$ & .945 & .706 & -.015 & .540 & .393 & .025 \\
\hline Good & $\mathrm{F}$ & .972 & -.697 & -.065 & -.526 & -.437 & -.114 \\
\hline Wanted to sing and dance & $\mathrm{Be}$ & .925 & -.684 & .143 & -.522 & -.386 & -.121 \\
\hline Wanted to run away in any direction & $\mathrm{Be}$ & .923 & .680 & .177 & .440 & .483 & .051 \\
\hline Feeling warm & Bo & .907 & -.679 & -.016 & -.533 & -.342 & -.211 \\
\hline $\begin{array}{l}\text { The event involved the violation of socially accepted } \\
\text { norms }\end{array}$ & Ev & .841 & .677 & .226 & .411 & .330 & .232 \\
\hline Wanted to stop what he/she was doing & $\mathrm{Be}$ & .907 & .668 & -.099 & .621 & .254 & -.018 \\
\hline Bad & $\mathrm{F}$ & .953 & .657 & -.030 & .602 & .398 & -.005 \\
\hline Wanted to comply with someone else's wishes & $\mathrm{Be}$ & .675 & -.647 & -.361 & .124 & -.192 & -.273 \\
\hline Stomach disturbance & Bo & .947 & .642 & .085 & .508 & .507 & .108 \\
\hline
\end{tabular}




\begin{tabular}{|c|c|c|c|c|c|c|c|}
\hline Feature & Comp. & Comm. & Valence & Arousal & $\begin{array}{c}\text { Power } \\
\text { Motivation }\end{array}$ & $\begin{array}{c}\text { Power } \\
\text { Potential }\end{array}$ & Novelty \\
\hline Wanted to disappear or hide from others & $\mathrm{Be}$ & .921 & .592 & -.108 & .530 & .527 & -.002 \\
\hline The person could live with the consequences of the event & Ev & .811 & -.586 & -.249 & -.368 & -.450 & -.262 \\
\hline Feeling cold & Bo & .898 & .582 & -.281 & .580 & .381 & .011 \\
\hline $\begin{array}{l}\text { The event was important for and relevant to the goals or } \\
\text { needs of somebody else }\end{array}$ & Ev & .629 & -.573 & .139 & -.369 & -.381 & -.030 \\
\hline Restless & $\mathrm{F}$ & .871 & .558 & .466 & .400 & .335 & .264 \\
\hline There was no urgency in the situation involving the event & Ev & .877 & -.558 & -.544 & -.274 & -.341 & -.279 \\
\hline Rapid heart rate & Bo & .934 & -.136 & .881 & -.170 & .156 & .293 \\
\hline Spoke more slowly & Ex & .934 & -.114 & -.873 & .008 & .130 & -.377 \\
\hline Rapid breathing & Bo & .900 & -.082 & .869 & -.035 & .171 & .328 \\
\hline Slowed heart rate & Bo & .955 & -.170 & -.855 & -.004 & -.190 & -.400 \\
\hline Slowed breathing & Bo & .930 & -.189 & -.854 & -.092 & -.120 & -.377 \\
\hline Wanted to do nothing & $\mathrm{Be}$ & .871 & -.077 & -.817 & .340 & .105 & -.269 \\
\hline Tense muscles & Bo & .839 & .222 & .795 & .015 & .113 & .381 \\
\hline Spoke more rapidly & Ex & .875 & -.162 & .782 & -.219 & -.232 & .368 \\
\hline Tired & $\mathrm{F}$ & .904 & .150 & -.780 & .432 & -.138 & -.259 \\
\hline Sweating & Bo & .812 & .267 & .755 & .114 & .258 & .302 \\
\hline Spoke more loudly & Ex & .836 & -.092 & .728 & -.162 & -.409 & .323 \\
\hline Closed the eyes & Ex & .855 & -.180 & -.715 & -.101 & .197 & -.513 \\
\hline The event required an immediate response & Ev & .772 & .513 & .612 & -.067 & -.049 & .357 \\
\hline Calm & $\mathrm{F}$ & .913 & -.469 & -.601 & -.247 & -.333 & -.401 \\
\hline Wanted to tackle the situation & $\mathrm{Be}$ & .852 & -.176 & .324 & -.727 & -.428 & .077 \\
\hline $\begin{array}{l}\text { The event was important for and relevant to the person's } \\
\text { goals or needs }\end{array}$ & Ev & .861 & -.510 & .152 & -.705 & -.253 & -.130 \\
\hline The event was caused by somebody else's behavior & Ev & .706 & -.126 & .314 & .671 & .116 & .357 \\
\hline
\end{tabular}




\begin{tabular}{|c|c|c|c|c|c|c|c|}
\hline Feature & Comp. & Comm. & Valence & Arousal & $\begin{array}{c}\text { Power } \\
\text { Motivation }\end{array}$ & $\begin{array}{c}\text { Power } \\
\text { Potential }\end{array}$ & Novelty \\
\hline Wanted someone else to take the initiative & $\mathrm{Be}$ & .818 & .061 & -.573 & 671 & .156 & -.105 \\
\hline $\begin{array}{l}\text { Lacked the motivation to pay attention to what was } \\
\text { happening }\end{array}$ & $\mathrm{Be}$ & .868 & .459 & -.477 & .638 & .052 & -.138 \\
\hline Strong & $\mathrm{F}$ & .913 & -.453 & .189 & -.628 & -.522 & -.066 \\
\hline Weak & $\mathrm{F}$ & .863 & .345 & -.323 & .617 & .496 & -.114 \\
\hline Wanted to overcome an obstacle & $\mathrm{Be}$ & .765 & .209 & .519 & -.545 & -.391 & .049 \\
\hline Awake & $\mathrm{F}$ & .807 & -.402 & .448 & -.497 & -.433 & .095 \\
\hline Spoke in a trembling voice & Ex & .911 & .183 & .194 & .143 & .884 & .193 \\
\hline Had tears in the eyes & Ex & .846 & -.316 & .123 & -.140 & .775 & -.332 \\
\hline Spoke in a firm voice & Ex & .880 & -.218 & .178 & -.448 & -.764 & -.127 \\
\hline Had speech disturbances & Ex & .809 & .131 & .181 & .204 & .720 & .445 \\
\hline $\begin{array}{l}\text { The person had a dominant role in the situation involving } \\
\text { the event }\end{array}$ & Ev & .855 & -.246 & .088 & -.511 & -.686 & -.236 \\
\hline Feeling weak in the limbs & Bo & .892 & .264 & -.411 & .435 & .681 & .010 \\
\hline $\begin{array}{l}\text { The person had control over the consequences of the } \\
\text { event }\end{array}$ & Ev & .918 & -.340 & -.136 & -.476 & -.660 & -.350 \\
\hline $\begin{array}{l}\text { The person was powerless in this situation involving the } \\
\text { event }\end{array}$ & $\mathrm{Ev}$ & .864 & .388 & .048 & .519 & .649 & .146 \\
\hline Becoming pale & Bo & .889 & .492 & -.090 & .424 & .645 & .206 \\
\hline The person had power over the consequences of the event & Ev & .857 & -.328 & -.063 & -.512 & -.617 & -.321 \\
\hline The event confirmed the expectations of the person & Ev & .894 & -.475 & -.209 & -.270 & -.548 & -.501 \\
\hline The event had consequences that were predictable & Ev & .733 & -.265 & -.334 & .064 & -.526 & -.521 \\
\hline The event was uncontrollable & Ev & .823 & .331 & .291 & .413 & .521 & .432 \\
\hline The event was caused by the persons own behavior & Ev & .753 & -.199 & -.101 & -.429 & -.517 & -.502 \\
\hline Raised the eyebrows & Ex & .869 & .221 & .217 & .055 & -.108 & .871 \\
\hline
\end{tabular}


DIMENSIONS AND CLUSTERS OF AESTHETIC EMOTIONS

\begin{tabular}{lccccccc}
\hline \multicolumn{1}{c}{ Feature } & Comp. & Comm. & Valence & Arousal & $\begin{array}{c}\text { Power } \\
\text { Motivation }\end{array}$ & $\begin{array}{c}\text { Power } \\
\text { Potential }\end{array}$ & $\begin{array}{c}\text { Novelty } \\
\text { Dropped their jaw }\end{array}$ \\
The event occurred suddenly & Ex & .824 & -.071 & .188 & -.216 & .132 & $\mathbf{. 8 4 8}$ \\
The event was unpredictable & Ev & .833 & -.173 & .516 & -.090 & .071 & $\mathbf{. 7 2 4}$ \\
The event happened by chance & Ev & .804 & -.047 & .494 & .141 & .138 & $\mathbf{. 7 2 1}$ \\
\hline
\end{tabular}

Note. Comp. = Component according to the CPM. Comm. = Communality. F=Subjective Feeling, Bo=Bodily Reactions, Ex=Expression,

$\mathrm{Be}=$ Behavior Tendencies, $\mathrm{Ev}=$ Event Evaluation. Boldface indicates the highest loading of each feature. The feature loadings indicate that the two dimensions valence and power are inverted: for valence, positive loadings represent negative valence; for both power dimensions, positive loadings stand for low power, and vice versa. 
DIMENSIONS AND CLUSTERS OF AESTHETIC EMOTIONS

\section{Supplementary Table 5}

Cluster Centers for the 15 Clusters and Each GRID Feature

\begin{tabular}{|c|c|c|c|c|c|c|c|c|c|c|c|c|c|c|c|}
\hline Feature & 1 & 2 & 3 & 4 & 5 & 6 & 7 & 8 & 9 & 10 & 11 & 12 & 13 & 14 & 15 \\
\hline 3 Good & 0.87 & -0.14 & 1.92 & -2.68 & 2.21 & 2.12 & 1.12 & 2.81 & 0.55 & -2.95 & 3.32 & -2.90 & 3.17 & -0.89 & -3.21 \\
\hline 4 Tired & -2.25 & -0.29 & -2.77 & -1.30 & -2.19 & -1.59 & -1.73 & 1.45 & -2.28 & -0.52 & -0.67 & -0.36 & -1.57 & 3.29 & -2.13 \\
\hline 5 Restless & 0.49 & -0.29 & 0.46 & 1.99 & -0.07 & -0.75 & 0.33 & -2.08 & 0.14 & 1.38 & -1.70 & 1.43 & -1.19 & -0.29 & 1.90 \\
\hline 6 Strong & 0.29 & -0.94 & 2.24 & -2.12 & 1.75 & 1.11 & 1.27 & 0.69 & 0.24 & -2.27 & 1.92 & -1.30 & 2.04 & -0.83 & -0.35 \\
\hline 7 Calm & -0.84 & 0.73 & -1.29 & -2.79 & -0.57 & 0.80 & -0.29 & 3.31 & -1.42 & -1.71 & 2.68 & -1.76 & 1.14 & 1.21 & -3.45 \\
\hline $8 \mathrm{Bad}$ & -1.04 & 0.35 & -1.84 & 1.82 & -2.33 & -2.24 & -1.45 & -1.86 & -1.15 & 2.33 & -2.56 & 2.44 & -2.84 & 1.23 & 1.66 \\
\hline 9 Weak & -0.68 & 0.72 & -2.34 & 0.95 & -1.63 & -1.38 & -0.90 & -0.45 & -1.15 & 1.51 & -1.24 & 0.39 & -1.67 & 1.17 & -0.36 \\
\hline 10 Awake & 1.42 & -0.09 & 2.70 & -0.31 & 2.33 & 1.33 & 2.31 & 0.26 & 1.36 & -1.20 & 1.64 & -0.08 & 2.07 & -1.11 & 0.29 \\
\hline 11 Feeling weak in & 0.59 & 1.14 & -2.21 & 1.25 & -1.60 & -0.22 & -1.05 & -0.15 & -0.48 & 2.07 & -1.64 & 0.62 & -1.59 & 1.28 & -1.21 \\
\hline 12 Becoming pale & 0.31 & 0.16 & -1.93 & 1.58 & -1.94 & -1.26 & -0.99 & -1.84 & 0.51 & 1.86 & -1.86 & 1.41 & -2.01 & -0.32 & -0.12 \\
\hline 13 Stomach disturbance & -0.67 & 0.09 & -2.02 & 1.66 & -2.13 & -1.90 & -1.29 & -2.21 & -0.49 & 2.40 & -2.67 & 2.03 & -2.52 & -0.99 & 2.02 \\
\hline 14 Slowed heart rate & -1.43 & 0.56 & -2.34 & -2.38 & -1.69 & -0.20 & -1.48 & 3.28 & -2.13 & -0.76 & 1.48 & -1.34 & -0.61 & 2.84 & -3.16 \\
\hline 15 Rapid heart rate & 1.89 & 0.26 & 2.50 & 1.92 & 2.01 & 1.08 & 1.26 & -1.69 & 1.66 & 0.42 & -0.19 & 0.74 & 1.72 & -1.83 & 2.42 \\
\hline 16 Tense muscles & 0.76 & -0.89 & 1.83 & 1.58 & 0.97 & 0.62 & 0.61 & -1.86 & 1.27 & 0.45 & -1.20 & 1.15 & 0.43 & -1.60 & 2.27 \\
\hline 17 Slowed breathing & -0.84 & 0.67 & -2.28 & -1.77 & -1.22 & 0.40 & -0.29 & 3.63 & -1.92 & -0.62 & 1.62 & -1.13 & -0.21 & 2.37 & -2.40 \\
\hline 18 Rapid breathing & 1.42 & -0.08 & 2.15 & 1.86 & 1.66 & 0.56 & 0.32 & -1.75 & 1.47 & 0.05 & -0.50 & 0.74 & 1.16 & -1.71 & 2.45 \\
\hline 19 Feeling warm & 1.14 & 0.39 & 1.47 & -1.59 & 1.74 & 1.98 & 0.53 & 2.80 & 0.24 & -2.14 & 2.64 & -2.03 & 2.70 & -0.72 & -0.95 \\
\hline 20 Sweating & 0.54 & -1.04 & 0.88 & 1.31 & 0.31 & -0.54 & 0.46 & -1.89 & 0.57 & 0.76 & -1.52 & 0.23 & -0.23 & -1.73 & 2.09 \\
\hline 21 Feeling cold & -0.95 & -0.05 & -2.06 & 0.62 & -2.04 & -1.37 & -1.44 & -1.30 & -0.97 & 1.76 & -1.54 & 1.30 & -2.25 & 1.06 & -0.50 \\
\hline 22 Smiled & 0.65 & -0.10 & 1.84 & -2.90 & 2.67 & 2.46 & 0.42 & 2.50 & 0.32 & -2.80 & 3.42 & -3.26 & 3.56 & -1.21 & -3.12 \\
\hline 23 Dropped their jaw & 0.77 & -1.70 & 0.32 & 0.68 & 0.55 & 0.66 & -0.08 & -1.69 & 3.17 & -2.16 & -1.52 & 0.24 & -0.39 & -1.76 & 0.11 \\
\hline 24 Raised the eyebrows & -0.13 & -1.61 & 0.39 & 0.92 & 0.26 & -0.25 & 0.73 & -1.60 & 2.62 & -1.68 & -1.27 & 0.62 & -0.83 & -0.74 & 0.23 \\
\hline 25 Frowned & -1.38 & -1.06 & -0.99 & 1.30 & -1.78 & -1.16 & 1.00 & -1.47 & 1.04 & 0.14 & -2.00 & 2.03 & -2.04 & -0.06 & 1.06 \\
\hline
\end{tabular}




\begin{tabular}{|c|c|c|c|c|c|c|c|c|c|c|c|c|c|c|c|}
\hline Feature & 1 & 2 & 3 & 4 & 5 & 6 & 7 & 8 & 9 & 10 & 11 & 12 & 13 & 14 & 15 \\
\hline 26 Closed the eyes & 0.64 & 2.28 & -1.77 & -0.82 & -0.63 & 0.91 & 0.20 & 3.51 & -2.36 & 0.52 & 1.64 & 0.17 & 0.72 & 2.36 & -1.51 \\
\hline 27 Had tears in the eyes & 1.96 & 2.31 & -0.69 & 0.03 & 0.01 & 0.47 & -1.38 & -0.96 & -0.87 & 2.04 & -0.16 & -1.04 & 0.63 & -1.61 & 0.48 \\
\hline 28 Spoke more loudly & -0.20 & -1.59 & 1.75 & 0.10 & 1.68 & 0.17 & 0.17 & -1.77 & 1.36 & -1.51 & -0.19 & 0.04 & 1.11 & -1.43 & 2.37 \\
\hline 29 Spoke in a trembling voice & 1.67 & 1.36 & -0.72 & 1.94 & -0.63 & 0.26 & -0.67 & -1.53 & 0.60 & 1.86 & -1.55 & 0.08 & -0.97 & -1.50 & 1.44 \\
\hline 30 Spoke in a firm voice & -1.20 & -0.97 & 1.62 & -1.82 & 1.37 & 0.66 & 0.97 & 0.40 & -0.17 & -2.12 & 1.83 & -0.31 & 1.29 & -0.38 & 0.10 \\
\hline 31 Had speech disturbances & 1.17 & 0.39 & -0.59 & 1.47 & -0.19 & 0.52 & -0.06 & -0.95 & 1.54 & 1.18 & -1.21 & 0.03 & -0.96 & -0.84 & 1.68 \\
\hline 32 Spoke more rapidly & 0.33 & -1.14 & 2.18 & 0.81 & 1.90 & 0.45 & 0.75 & -1.77 & 1.60 & -1.41 & -0.67 & -0.46 & 1.28 & -1.68 & 2.26 \\
\hline 33 Spoke more slowly & 0.24 & 1.55 & -1.95 & -0.87 & -1.29 & 0.50 & 0.11 & 3.13 & -1.10 & 0.97 & 1.39 & -0.53 & -0.05 & 2.87 & -2.25 \\
\hline $\begin{array}{l}34 \text { Wanted the ongoing } \\
\text { situation to last or be repeated }\end{array}$ & 1.43 & 0.58 & 2.20 & -2.74 & 3.11 & 2.62 & 1.03 & 2.64 & 0.76 & -3.10 & 3.65 & -3.47 & 3.76 & -1.78 & -2.64 \\
\hline $\begin{array}{l}35 \text { Wanted to stop what he/she } \\
\text { was doing }\end{array}$ & -0.91 & -0.06 & -1.31 & 1.09 & -1.63 & -1.56 & -0.48 & -1.02 & -0.50 & 1.73 & -1.30 & 1.76 & -1.75 & 1.88 & 1.57 \\
\hline $\begin{array}{l}36 \text { Wanted to undo what was } \\
\text { happening }\end{array}$ & -1.22 & 0.58 & -1.33 & 1.73 & -2.35 & -2.34 & -0.83 & -1.55 & -0.63 & 2.32 & -2.01 & 2.27 & -2.60 & 0.63 & 2.02 \\
\hline $\begin{array}{l}37 \text { Wanted to comply with } \\
\text { someone else's wishes }\end{array}$ & -0.46 & 0.38 & -1.01 & -1.13 & -0.14 & -0.66 & -0.52 & -0.02 & -0.77 & -0.90 & 0.07 & -1.06 & 0.08 & 0.36 & -1.61 \\
\hline $\begin{array}{l}38 \text { Wanted someone else to } \\
\text { take the initiative }\end{array}$ & -0.36 & 0.41 & -1.83 & 0.53 & -1.04 & -0.94 & -1.16 & 0.95 & -0.80 & 0.59 & -0.52 & 0.20 & -1.04 & 2.42 & -1.21 \\
\hline 39 Wanted to do nothing & -0.56 & 0.45 & -2.72 & -0.98 & -1.67 & -0.36 & -1.77 & 2.18 & -1.54 & 0.82 & 0.13 & -0.24 & -0.62 & 2.77 & -1.95 \\
\hline $\begin{array}{l}40 \text { Lacked the motivation to } \\
\text { pay attention to what was } \\
\text { happening }\end{array}$ & -1.51 & -0.38 & -2.48 & 0.23 & -2.21 & -1.76 & -1.72 & -0.01 & -1.86 & 0.91 & -1.41 & 1.01 & -2.07 & 4.00 & -0.60 \\
\hline $\begin{array}{l}41 \text { Wanted to disappear or hide } \\
\text { from others }\end{array}$ & -0.59 & 0.39 & -2.11 & 1.61 & -2.35 & -1.93 & -1.03 & -1.54 & -1.14 & 2.51 & -1.97 & 1.96 & -2.65 & 0.01 & -0.35 \\
\hline $\begin{array}{l}42 \text { Wanted to do damage, hit, } \\
\text { or say something that hurts }\end{array}$ & -1.52 & -0.99 & -0.66 & 0.93 & -2.08 & -2.28 & -1.37 & -2.46 & -0.56 & 0.67 & -2.44 & 1.52 & -2.63 & -0.78 & 2.48 \\
\hline
\end{tabular}


DIMENSIONS AND CLUSTERS OF AESTHETIC EMOTIONS

\begin{tabular}{|c|c|c|c|c|c|c|c|c|c|c|c|c|c|c|c|}
\hline Feature & 1 & 2 & 3 & 4 & 5 & 6 & 7 & 8 & 9 & 10 & 11 & 12 & 13 & 14 & 15 \\
\hline $\begin{array}{l}43 \text { Wanted to oppose someone } \\
\text { or something }\end{array}$ & -0.73 & -0.78 & 0.26 & 0.58 & -0.62 & -1.01 & 0.08 & -1.93 & -0.13 & 0.86 & -1.41 & 1.46 & -1.51 & -0.44 & 2.72 \\
\hline $\begin{array}{l}44 \text { Wanted to tackle the } \\
\text { situation }\end{array}$ & 0.18 & -0.35 & 1.93 & -0.62 & 1.10 & 0.99 & 1.90 & -0.33 & 0.50 & -1.44 & 0.64 & -0.78 & 1.28 & -1.35 & -0.18 \\
\hline $\begin{array}{l}45 \text { Wanted to overcome an } \\
\text { obstacle }\end{array}$ & -0.46 & -0.47 & 1.44 & -0.45 & 0.63 & -0.08 & 1.41 & -1.21 & -0.10 & -0.65 & -0.09 & -0.44 & 0.07 & -0.79 & 0.60 \\
\hline $\begin{array}{l}46 \text { Wanted to run away in any } \\
\text { direction }\end{array}$ & -0.52 & -0.04 & -1.29 & 1.99 & -1.98 & -2.06 & -1.04 & -2.35 & -0.51 & 2.11 & -2.31 & 1.75 & -2.42 & -0.97 & 1.36 \\
\hline 47 Wanted to sing and dance & 0.08 & -0.21 & 1.96 & -3.09 & 2.64 & 1.71 & -0.54 & 0.65 & -0.19 & -3.38 & 1.73 & -3.31 & 2.87 & -1.84 & -2.79 \\
\hline $\begin{array}{l}48 \text { The event occurred } \\
\text { suddenly }\end{array}$ & 1.00 & 0.04 & 1.40 & 1.46 & 1.37 & 1.17 & 1.20 & -0.31 & 2.74 & 0.17 & -0.01 & 0.49 & 0.80 & -0.55 & 1.16 \\
\hline $\begin{array}{l}49 \text { The event was } \\
\text { unpredictable }\end{array}$ & 0.77 & 0.50 & 1.35 & 1.49 & 1.29 & 0.54 & 0.77 & -0.37 & 2.24 & 0.47 & 0.17 & 0.85 & 0.39 & -0.38 & 1.10 \\
\hline $\begin{array}{l}50 \text { The event confirmed the } \\
\text { expectations of the person }\end{array}$ & -0.90 & -0.71 & -0.13 & -2.15 & 0.32 & 0.35 & -0.65 & 1.49 & -2.12 & -1.21 & 1.70 & -1.71 & 1.28 & 0.65 & -1.77 \\
\hline $\begin{array}{l}51 \text { The event was pleasant for } \\
\text { the person }\end{array}$ & 0.93 & 0.02 & 1.96 & -2.82 & 2.77 & 2.07 & 0.81 & 3.05 & 0.30 & -3.09 & 3.54 & -3.31 & 3.54 & -0.85 & -3.10 \\
\hline $\begin{array}{l}52 \text { The event was important for } \\
\text { and relevant to the person's } \\
\text { goals or needs }\end{array}$ & 0.98 & 0.63 & 2.01 & -0.21 & 1.59 & 1.38 & 1.67 & 1.37 & 0.34 & -0.99 & 1.78 & -0.86 & 2.03 & -1.29 & -0.93 \\
\hline $\begin{array}{l}53 \text { The event was important for } \\
\text { and relevant to the goals or } \\
\text { needs of somebody else }\end{array}$ & 0.57 & -0.30 & 0.83 & -0.41 & 0.66 & 0.38 & 0.27 & 0.19 & 0.07 & -0.94 & 0.56 & -0.71 & 0.96 & -0.10 & -0.55 \\
\hline $\begin{array}{l}54 \text { The event happened by } \\
\text { chance }\end{array}$ & 0.70 & 0.19 & 1.11 & 0.82 & 1.17 & 0.52 & 0.58 & 0.14 & 2.09 & 0.05 & 0.22 & 0.31 & 0.78 & -0.14 & 0.26 \\
\hline $\begin{array}{l}55 \text { The event was caused by } \\
\text { the person's own behavior }\end{array}$ & -0.76 & -0.41 & 0.12 & -1.15 & -0.08 & -0.37 & 0.23 & 0.78 & -1.64 & -0.49 & 0.55 & -1.08 & 0.59 & -0.20 & -0.71 \\
\hline
\end{tabular}


DIMENSIONS AND CLUSTERS OF AESTHETIC EMOTIONS

\begin{tabular}{|c|c|c|c|c|c|c|c|c|c|c|c|c|c|c|c|}
\hline Feature & 1 & 2 & 3 & 4 & 5 & 6 & 7 & 8 & 9 & 10 & 11 & 12 & 13 & 14 & 15 \\
\hline $\begin{array}{l}56 \text { The event was caused by } \\
\text { somebody else's behavior }\end{array}$ & 0.88 & 1.04 & 0.97 & 1.21 & 1.05 & 0.70 & 0.30 & 0.18 & 1.66 & 0.92 & 0.45 & 1.31 & 0.75 & 0.86 & 1.44 \\
\hline $\begin{array}{l}57 \text { The event had consequences } \\
\text { that were predictable }\end{array}$ & -0.42 & -0.35 & -0.62 & -1.03 & 0.04 & -0.27 & 0.14 & 1.18 & -1.93 & -0.74 & 1.21 & -0.31 & 0.49 & 1.34 & -1.24 \\
\hline $\begin{array}{l}58 \text { The event had negative, } \\
\text { undesirable consequences for } \\
\text { the person }\end{array}$ & -0.83 & 0.09 & -1.08 & 1.86 & -2.15 & -1.63 & -0.51 & -1.92 & -0.30 & 2.81 & -2.38 & 2.03 & -2.75 & -0.49 & 2.57 \\
\hline $\begin{array}{l}59 \text { The event required an } \\
\text { immediate response }\end{array}$ & -0.37 & -0.68 & 1.49 & 0.99 & 0.63 & -0.35 & 1.01 & -1.21 & 0.79 & 0.21 & -1.23 & 0.53 & -0.64 & -0.96 & 1.09 \\
\hline $\begin{array}{l}60 \text { The person had power over } \\
\text { the consequences of the event }\end{array}$ & -0.53 & -0.94 & 0.68 & -2.11 & 0.56 & 0.29 & 0.80 & 1.14 & -1.28 & -1.40 & 1.24 & -1.16 & 0.94 & -0.34 & -1.41 \\
\hline $\begin{array}{l}61 \text { The person had control over } \\
\text { the consequences of the event }\end{array}$ & -0.71 & -1.04 & 0.47 & -2.31 & 0.50 & -0.20 & 0.53 & 1.19 & -1.39 & -1.76 & 1.62 & -1.57 & 1.13 & 0.27 & -1.50 \\
\hline $\begin{array}{l}62 \text { The person could live with } \\
\text { the consequences of the event }\end{array}$ & 1.00 & 0.34 & 0.43 & -1.15 & 1.56 & 2.02 & 0.74 & 2.31 & 0.05 & -0.80 & 2.55 & -0.81 & 1.67 & 0.74 & -1.76 \\
\hline $\begin{array}{l}63 \text { The event was inconsistent } \\
\text { with the person's own } \\
\text { standards and ideals }\end{array}$ & -0.75 & -0.08 & -0.58 & 1.70 & -1.57 & -1.24 & -0.59 & -1.66 & 0.12 & 2.33 & -1.85 & 2.36 & -2.33 & 0.09 & 2.57 \\
\hline $\begin{array}{l}64 \text { The event involved the } \\
\text { violation of socially accepted } \\
\text { norms }\end{array}$ & -0.48 & -0.27 & -0.05 & 1.20 & -1.03 & -1.15 & -0.46 & -1.63 & 1.15 & 2.32 & -1.51 & 2.17 & -1.92 & -0.76 & 2.23 \\
\hline $\begin{array}{l}65 \text { The person was powerless } \\
\text { in this situation involving the } \\
\text { event }\end{array}$ & 0.59 & 0.96 & -0.74 & 2.04 & -0.69 & 0.22 & -0.41 & -0.79 & 0.53 & 2.46 & -1.30 & 0.86 & -1.33 & 0.47 & 1.76 \\
\hline $\begin{array}{l}66 \text { The person had a dominant } \\
\text { role in the situation involving } \\
\text { the event }\end{array}$ & -1.04 & -1.04 & 0.67 & -1.95 & 0.60 & -0.15 & 0.43 & 0.10 & -0.72 & -1.27 & 1.19 & -1.31 & 0.74 & -0.47 & -0.50 \\
\hline
\end{tabular}


DIMENSIONS AND CLUSTERS OF AESTHETIC EMOTIONS

\begin{tabular}{|c|c|c|c|c|c|c|c|c|c|c|c|c|c|c|c|}
\hline Feature & 1 & 2 & 3 & 4 & 5 & 6 & 7 & 8 & 9 & 10 & 11 & 12 & 13 & 14 & 15 \\
\hline $\begin{array}{l}67 \text { There was no urgency in the } \\
\text { situation involving the event }\end{array}$ & 0.61 & 0.56 & -0.26 & -1.47 & 0.37 & 1.41 & -0.33 & 3.04 & -0.69 & -1.36 & 2.05 & -0.98 & 1.57 & 1.70 & -1.64 \\
\hline $\begin{array}{l}68 \text { The event was } \\
\text { uncontrollable }\end{array}$ & 0.36 & 0.98 & 0.45 & 1.84 & 0.14 & -0.22 & 0.07 & -1.19 & 1.71 & 1.40 & -1.06 & 1.07 & -0.57 & -0.19 & 1.41 \\
\hline
\end{tabular}

Note. Cluster names: 1 = moved/in awe, $2=$ longing $/$ melancholic, $3=$ invigorated $/$ interested, $4=$ confused $/$ worried, $5=\mathrm{merry} /$ attracted, $6=$

fascinated/enchanted, $7=$ intellectually stimulated, $8=$ relaxed, $9=$ surprised, $10=\mathrm{sad}, 11=$ pleased $/$ feeling harmony, $12=\mathrm{displeased} / \mathrm{repelled}$, $13=$ delighted/feeling beauty, $14=$ bored, $15=$ angry . 


\section{Supplementary Table 6}

Mean Jaccard Similarity Values

\begin{tabular}{lc}
\hline \multicolumn{1}{c}{ Cluster } & Mean Jaccard similarity value \\
\hline Moved / Awe & 0.85 \\
Longing / Melancholic & 0.75 \\
Invigorated / Interested & 0.71 \\
Confused / Worried & 0.71 \\
Merry / Attracted & 0.71 \\
Fascinated / Enchanted & 0.74 \\
Intellectually Stimulated & 0.93 \\
Relaxed & 0.83 \\
Surprised & 0.90 \\
Sad & 0.72 \\
Pleased / Harmony & 0.68 \\
Displeased / Repelled & 0.89 \\
Delighted / Feeling beauty & 0.87 \\
Bored & 0.95 \\
Angry & 0.86 \\
\hline
\end{tabular}




\section{Supplementary Figure 1}

Exemplary Illustration of the Aesthetic Emotion GRID task for one feature of one category.

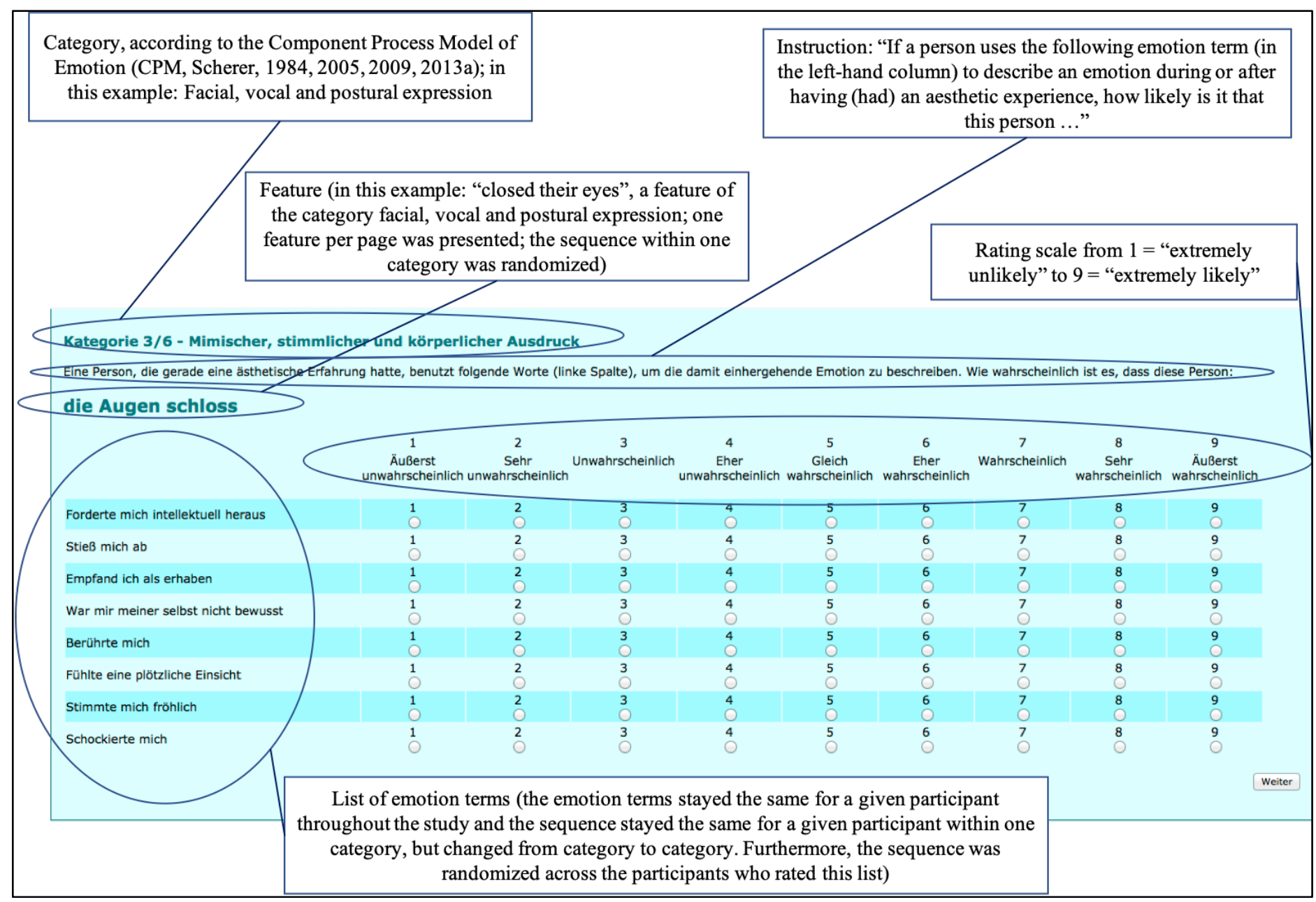


Supplementary Figure 2

Screeplot of the PCA on the Aesthetic Emotion GRID

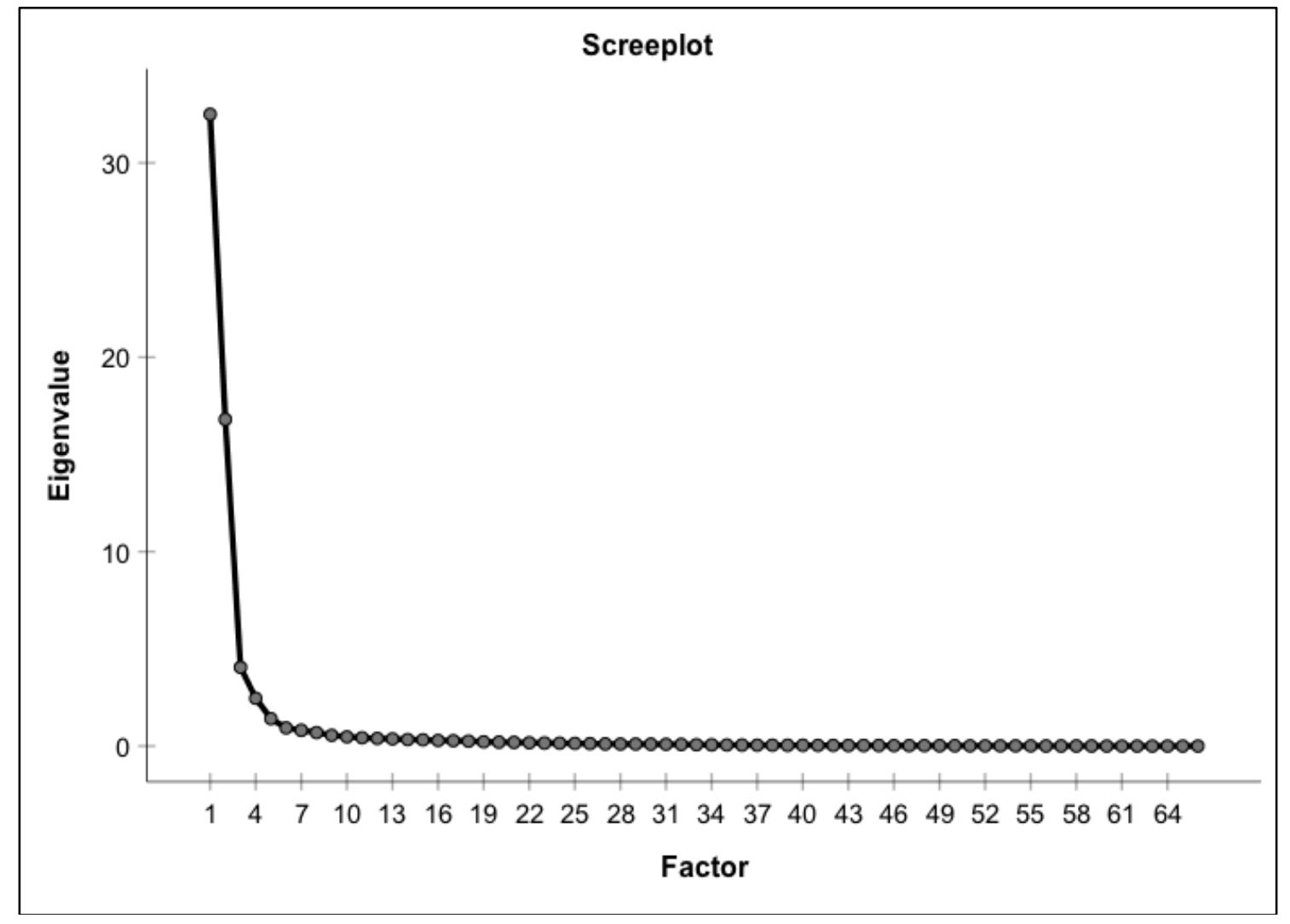




\section{Supplementary Figure 3}

Feature Scores of the 75 Emotion Terms Represented by the Four-dimensional Structure for Valence x Arousal (Panel A), Power x Arousal (B), and Valence x Novelty (C)
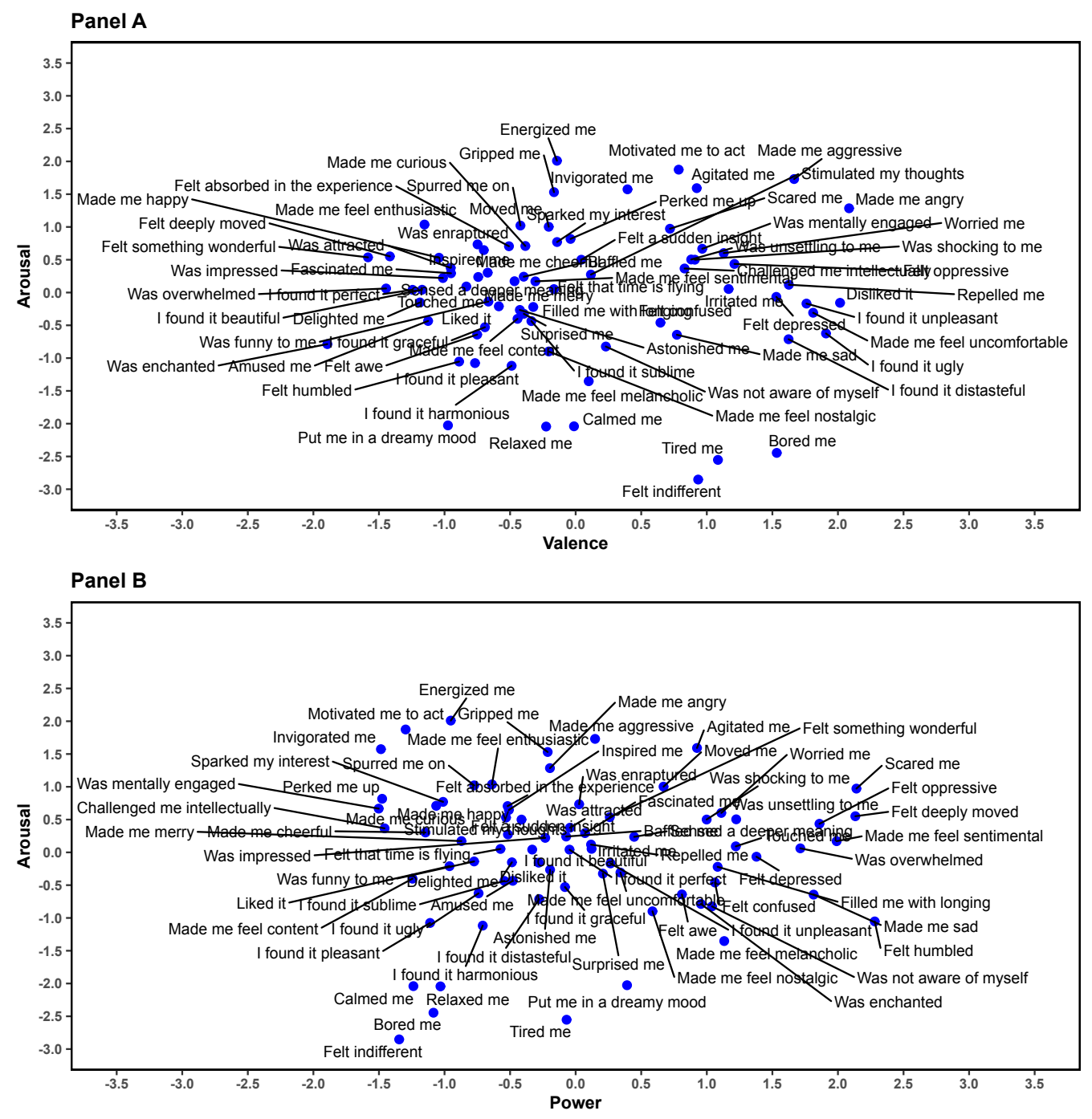

Panel C

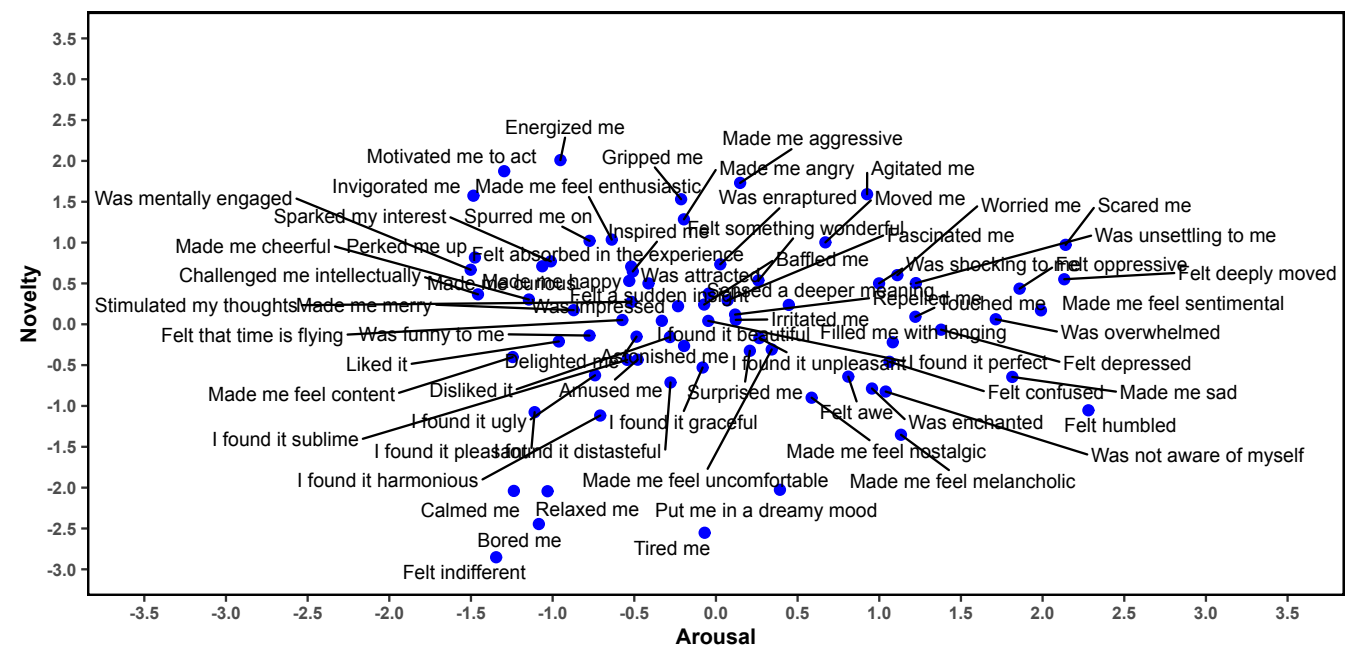




\section{Supplementary Figure 4}

The Gap Statistic for up to 50 Clusters Based on 100 Bootstrap Simulations per Number of Clusters

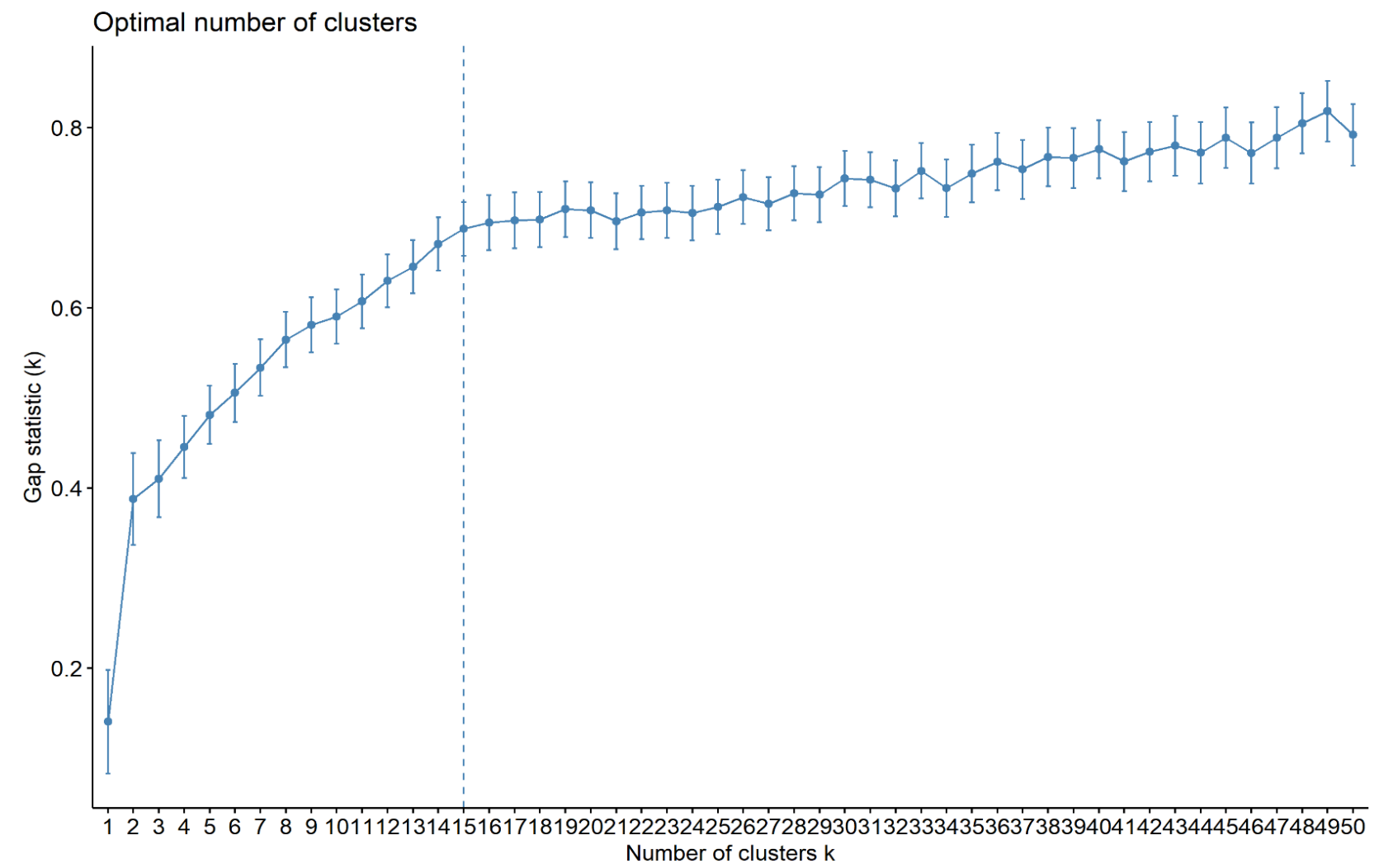

Note. The error bars represent the standard deviation of the simulation error. The optimal number of clusters based on the maxSE criterion as implemented in the R-package 'factoextra' is marked by a vertical, dotted line. 


\section{Cluster Analyses: Results of the Top and Bottom Five Features Characteristic for Each Cluster}

Using exploratory $k$-means cluster analysis, we derived 15 clusters from the semantic feature profiles of 75 emotion terms as determined specifically for the context of aesthetics. The cluster center scores for each GRID feature are reported in Table S3. To determine the features that are particularly characteristic for each cluster, we identified the five GRID features with the highest scores and the five GRID features with the lowest scores for each cluster. These are illustrated in Figure 3 and 4. For the sake of a better overview of the results, the clusters in Figure 3 and 4 are allocated according to the approximate position in relation to the two dimensions in the cluster plot of Figure 2.

The features of the clusters 15 "angry", 4 "confused/worried", 12 "displeased/repelled", and 10 "sad" (on the very left column of panels in Fig. 3) - support the interpretation of the low end of dimension 1 as negative valence in all five emotion components. Features representing low positive or high negative feelings, facial expressions, and event evaluations as well as a lack of appetitive or high avoidant behavior tendencies are characteristic of all four clusters. Specifically, the features "smiled" and "the event was pleasant for the person" were among the five GRID features with the lowest scores. Moreover, the cluster center scores for feeling "good" were among the lowest five scores in clusters 15, 12, and 10 and the sixth lowest in cluster 4 (see Table S3). The behavior tendency "wanted the ongoing situation to last or be repeated" was rated very low for clusters 4, 12, and 10 (it was ranked 7th among the low-scoring features for cluster 15). As a common feature for clusters 15,12 , and 10 , the evaluation of the event as "inconsistent with the person's own standards and ideals" was rated as high.

In contrast, analogue to Figure 2, the very right column of panels in Figure S5 presents three clusters that all include GRID features indicative of positive valence: clusters 5 "merry/attracted", 13 "delighted/feeling beauty", and 11 "pleased/feeling harmony." For clusters 13 and 11, the subjective feeling "good," the facial expression "smiled," the behavior tendency "wanted the ongoing situation to last or be repeated," and the evaluation "the event was pleasant for the person" represented four out of five GRID features with the highest scores. Smiling, seeking continued or repeated exposure, and evaluating the event as pleasant were also characteristic of cluster 5 (feeling good was ranked 6th; see Table S3).

The top clusters of Figure 2 and the top row of panels in Figure 3 and 4 represent the high end of dimension 2 (indicating high arousal) with four clusters. For clusters 15 "angry," 9 "surprised," 3 "invigorated/interested," and 5 "merry/attracted," subjective feelings of calmness (cluster 15) or tiredness (clusters 9, 3, and 5) as well as a "slowed heart rate" (clusters 15, 9, and 3) were considered uncharacteristic. Feeling "awake" was among the top-five high-scoring features in clusters 3 and 5.

The low end of dimension 2 is represented by two clusters included in the bottom row of clusters in Figure 2 and panels in Figure 3 and 4. Clusters 14 "bored" and 8 "relaxed" are clearly different in valence, as evidenced by a high score on feeling "tired" for cluster 14 and feeling "calm" for cluster 8. Nevertheless, both clusters share features indicative of low arousal: a "slowed heart rate" and "speaking more slowly."

Lastly, the clusters 1 "moved/in awe," 2 "longing/melancholic," and 7 "intellectually stimulated" (middle part of Figures 2; middle right of Fig. 3, middle left of Fig. 4) seem to be insufficiently described by the two dimensions valence and arousal. As revealed by Figure 3 and 4 , these clusters include a mixture of GRID features that might be cues to positive or negative valence. "Having tears in the eyes" and "speaking in a trembling voice" emerged as characteristic expressions in clusters 1 and 2, yet - unlike cluster 10 "sad"- the centers of both clusters do not show high scores for negative subjective feelings and avoidant behavior tendencies. On the contrary, the tendency to "want the ongoing situation to last or be repeated" was rated among the 
top five GRID features in cluster 1. None of the most prominent features of cluster 2 indicate noticeable degrees of high or low arousal. Cluster 7 was characterized by feeling "awake" along with behavior tendencies to "tackle the situation" and to "overcome an obstacle," while negative feelings or negative event evaluations were not characteristic of this cluster. To conclude, the analysis provides a structure of the aesthetic emotion terms into 15 clusters, based on similarities in the feature profiles of all five emotion components, that cover different nuances of aesthetic emotions. 